\title{
Locally Advanced Ureter Urothelial Carcinoma
}

National Cancer Institute

\section{Source}

National Cancer Institute. Locally Advanced Ureter Urothelial Carcinoma. NCI Thesaurus.

Code C162616.

A ureter urothelial carcinoma that has spread from its original site of growth to nearby tissues or lymph nodes. 